\title{
LOGOTERAPI MENINGKATKAN HARGA DIRI NARAPIDANA PEREMPUAN PENGGUNA NARKOTIKA
}

\author{
Sri Maryatun ${ }^{1 *}$, Achir Yani S. Hamid ${ }^{2}$, Mustikasari $^{2}$ \\ 1. PSIK Kekhususan Keperawatan Jiwa, Fakultas Kedokteran, Universitas Sriwijaya, Palembang 30128, Indonesia \\ 2. Fakultas Ilmu Keperawatan, Universitas Indonesia, Depok 16424, Indonesia \\ *E-mail: tunce79@yahoo.com
}

\begin{abstract}
Abstrak
Penyalahgunaan narkotika setiap tahunnya mengalami peningkatan termasuk pada kelompok perempuan. Seseorang dapat terjerumus pada penyalahgunaan narkotika ini karena sebelumnya mengalami masalah psikologis. Ketika mereka menjalani hukuman masalah psikologis tersebut dapat memburuk termasuk harga diri rendah. Logoterapi bertujuan meningkatkan harga diri melalui proses penemuan makna hidup. Tujuan penelitian adalah untuk mengidentifikasi pengaruh logoterapi terhadap harga diri narapidana perempuan pengguna narkotika di Lembaga Pemasyarakatan kelas IIA. Penelitian quasi experimental pre-post test with control group ini dilakukan pada 56 responden. Hasil penelitian menunjukkan bahwa terdapat perbedaan harga diri (kognitif, perilaku, afektif) yang signifikan pada kelompok intervensi sebelum dan sesudah diberikan logoterapi. Logoterapi oleh perawat professional perlu dipertimbangkan sebagai tindakan untuk mengatasi masalah psikologis seperti harga diri rendah, termasuk di lingkungan lembaga pemasyarakatan.
\end{abstract}

Kata kunci: harga diri rendah, logoterapi, narapidana perempuan, penyalahgunaan napza

\begin{abstract}
Logotherapy Improving Self Esteem of Femaleprisoner's Narcotics Users. Every year drug abused has increased, including women's groups. An inividu can be involved with drug abuse is because previous experience of psychological problems. When they are in jail the psychological problems may worsen, including low self-esteem. Logotherapy aims to increase self-esteem through the discovery of the meaning of life process. The purpose of this study was to identify the effect of logotherapy to self-esteem of women inmates at the Correctional Institution drug users IIA class. This quasi-experimental pre-post test with control group study was conducted on 56 respondents. The results showed that there were differences in self-esteem (cognitive, behavioral, and affective) significantly in the intervention group before and after logotherapy intervention. Logotherapy by professional nurses need to be considered as measures to overcome psychological problems such as low self-esteem, including within prisons.
\end{abstract}

Keywords: female prisoner, logotherapy, low self esteem, substance abused

\section{Pendahuluan}

Krisis multidimensi yang berkepanjangan terjadi di Indonesia beberapa tahun terakhir. Angka pengangguran yang meningkat $10 \%$ atau sekitar 23 juta orang pada tahun 2010 (Pujianto, 2010) dan angka kemiskinan yang masih tinggi yaitu $23 \%$ dari total penduduk menyebabkan rapuhnya ketahanan ekonomi nasional dan lemahnya ketahanan mental dan moral. Ketidakmampuan masyarakat dalam mengatasi stressor dan masalah hidup ini dapat menimbulkan masalah yang serius yaitu meningkatnya tindakan kriminalitas atau kejahatan (Mujiran, 2006). Berdasarkan catatan Mabes Polri tahun 2009, jenis kasus kriminalitas yang paling banyak diseluruh Indonesia adalah kasus narkoba. Data statistik Departemen Kehakiman dan HAM menunjukkan bahwa jumlah tahanan dan narapidana narkotika di Indonesia meningkat, tahun 2008 berjumlah 6.363 orang, di tahun 2009 menjadi 15.522 orang. Persentase angka kejahatan yang dilakukan perempuan juga meningkat $5 \%$ tiap tahunnya. 
Menurut Koesno (2007) meningkatnya angka kriminalitas oleh perempuan disebabkan beberapa faktor antara lain kemiskinan, kondisi ekonomi seperti merasa penghasilannya kurang, sulitnya memperoleh pekerjaan, pengangguran, adanya kebutuhan sesaat, kondisi lingkungan seperti longgarnya kontrol sosial dan kondisi kepribadian yang labil. Kriminalitas yang terjadi menimbulkan kerugian materi dan non-materi. Kerugian materi berupa pembayaran denda hukuman atau uang ganti rugi akibat tindakan kejahatan yang dilakukan. Kerugian non-materi berupa perasaan tidak nyaman, tertekan dan kehilangan. Perubahan status menjadi narapidana dan menjalani hukuman dalam rentang waktu yang cukup lama di Lembaga Permasyarakatan (Lapas) merupakan stressor bagi mereka. Stressor tersebut antara lain kehilangan keluarga, kehilangan kontrol diri, kehilangan model dan kurangnya dukungan. Kondisi ini dapat menimbulkan masalah psikologis (Lynch et al., 2014). Stress yang dialami narapidana semakin bertambah dengan adanya stigma di masyarakat yang memberikan label negatif kepada mereka sebagai penjahat dan pembuat kerusakan.

James dan Glaze (2006) menyampaikan bahwa narapidana perempuan di AS mengalami masalah kesehatan jiwa lebih tinggi (75\%) dibandingkan narapidana laki-laki (55\%). Sebanyak 30\% narapidana perempuan mengalami depresi. Nova (2008) mendapatkan $80 \%$ narapidana perempuan di Lapas Palembang mengalami depresi sedang. Kejadian depresi sebelumnya merupakan risiko depresi selanjutnya pada perempuan. Salah satu gejala yang muncul dari depresi adalah harga diri rendah. Narapidana yang memiliki harga diri rendah cendrung merasa tidak berguna, putus asa, tidak berdaya dan tidak mempunyai motivasi untuk bekerja dan beraktivitas (Videbeck, 2008). Inayatika (2012) juga menemukan kepercayaan diri pada narapidana perempuan di Palembang tergolong rendah dengan komponen percaya diri rendah, harga diri rendah dan gambaran diri rendah.

Untuk mengatasi masalah tersebut, melalui sistem pembinaan ketrampilan dan pembinaan mental berbagai upaya telah dilakukan di Lapas.
Akan tetapi, hasilnya belum memuaskan dan belum mampu mengatasi permasalahan psikologis narapidana. Salah satu bentuk upaya yang dapat dilakukan adalah dengan melibatkan perawat. Pelayanan keperawatan di Lapas atau Correctional Health Nursing (CHN), salah satunya adalah pemberian terapi yang berguna untuk membantu narapidana perempuan meningkatkan harga diri selama di Lapas dan setelah bebas (Ferszt, Hickey, \& Seleyman, 2013).

Di Indonesia, CHN dikenal dengan sebutan perawatan kesehatan masyarakat (perkesmas) yang memberikan pelayanan kesehatan masyarakat terutama kegiatan preventif dan promotif secara komprehensif. Logoterapi merupakan salah satu psikoterapi untuk meningkatkan harga diri melalui penemuan dan pencapaian makna. Logoterapi adalah suatu jenis psikoterapi yang pertamakali dikembangkan oleh Viktor Frankl tahun 1938 dengan mengutamakan makna hidup sebagai tema sentral. Frankl mengemukakan bahwa jika seseorang berhasil menemukan dan memenuhi makna hidupnya, maka kehidupan akan menjadi lebih berarti, berharga dan bahagia (Bastaman, 1996; Sutejo et al., 2011). Logoterapi juga dapat memulihkan para pengguna napza dari ketergantungan (Asagba, 2009).

Penerapan logoterapi pada narapidana perempuan pengguna narkotika dengan harga diri rendah perlu diuji untuk melihat pengaruhnya terhadap peningkatan harga diri. Tujuan penelitian ini adalah untuk mengidentifikasi pengaruh logoterapi terhadap harga diri narapidana perempuan pengguna narkotika di Lembaga Pemasyarakatan.

\section{Metode}

Penelitian kuasi eksperimenpre-post test with control groupinidilakukandi sebuah Lapas di Palembang setelah mendapat persetujuan dari komite etik penelitian Fakultas Ilmu Keperawatan Universitas Indonesia dan ijin administrasi dari Kepala Lapas. Sebanyak 56 narapidana perempuan yang diseleksi dengan tehnik pengambilan sampel secara acak dilibatkan. Mereka dibagi dalam kelompok intervensi dan kelompok kontrol yang masing-masing berjumlah 28 orang. 
Pengukuran harga diri dilakukan sebelum dan sesudah intervensi pada tiap kelompok. Kelompok intervensi diberikan terapi generalis berupa terapi aktivitas kelompok (TAK) dan logoterapi empat sesi yaitu sesi pertama pengkajian terhadap masalah yang dialami responden selama dipenjara. Sesi kedua, identifikasi alasan dan harapan mengikuti terapi yang diungkapkan. Sesi ketiga, pengambilan keputusan untuk memilih tiga makna yang paling penting dalam hidup responden serta memprakrekkan makna hidup tersebut dalam kegiatan sehari-hari. Sesi terakhir, evaluasi sesi sebelumnya disertai dengan respon umpan balik positif responden terhadap kegiatan logoterapi yang telah dilakukan. Kelompok kontrol hanya diberikan terapi generalis yaitu TAK. Setelah proses pengambilan data selesai, mereka juga diberikan logoterapi. Uji statistik yang digunakan adalah analisis independent tTest dan dependen/Pair t-Test, Chi-square, korelasi Pearson dan Anova dengan bantuan program komputer.

\section{Hasil}

Hasil penelitian menunjukkan rerata usia responden pada kelompok intervensi 35,57 tahun dan kelompok kontrol 33,54 tahun. Rerata lama masa hukuman sebagian besar responden pada kedua kelompok adalah 5,5 tahun. Mayoritas responden pada kelompok intervensi berpendidikan SMP, sedangkan pada kelompok kontrol adalah SD. Sebagian besar responden pada kedua kelompok tidak bekerja sebelumnya atau sebagai ibu rumah tangga. Pada kedua kelompok mayoritas telah menikah.

Hasil uji kesetaraan karateristik usia, lama masa hukuman, pendidikan, pekerjaan dan status perkawinan menggunakan uji Chi-Square menunjukkan bahwa kesetaraan dengan nilai $p>0,05$. Hasil analisis kesetaraan harga diri (komponen kognitif, perilaku, afektif) pada kelompok intervensi dan kontrol dengan menggunakan independen t-Test adalah setara dengan nilai $\mathrm{p}>0,05$ (Tabel 1).

Hasil uji kemaknaan didapatkan bahwa tidak ada perbedaan respon kognitif pada kelompok intervensi dan kontrol sebelum mendapatkan logoterapi dengan nilai $(\mathrm{p}=0,154, \alpha=0,05)$ (Tabel 1). Hasil analisis juga menunjukkan bahwa perubahan respon prilaku tidak bermakna secara statistik ( $p=0,353 ; \alpha=0,05)$. Hasil serupa ditunjukkan dari nilai 0,164 pada respon afektif berarti tidak ada perbedaan yang bermakna respon afektif pada kelompok intervensi dan kontrol sebelum diberikan logoterapi. Hasil analisis menunjukkan tidak ada perbedaan yang bermakna harga diri pada kelompok intervensi dan kontrol sebelum diberikan logoterapi $(\mathrm{p}=$ $0,287 ; \alpha=0,05)$.

Hasil analisis perbedaan harga diri (kognitif, perilaku, afektif) responden sebelum dilakukan logoterapi pada kedua kelompok memperlihatkan rerata kognitif, perilaku dan afektif tidak jauh berbeda. Rerata skor kognitif pada kelompok intervensi 38,39, rerata skor respon perilaku 28,29 dan skor afektif 23,64. Angka tersebut lebih tinggi dibanding rerata skor pada kelompok kontrol. Hal ini menunjukkan bahwa nilai tersebut tidak lebih baik dengan kelompok kontrol

Tabel 1. Uji Kesetaraan Harga Diri (Kognitif, Perilaku, Afektif)

\begin{tabular}{lllcc}
\hline Komponen & Kelompok & Rerata & $\mathrm{t}$ & $\mathrm{p}$ \\
\hline Kognitif & Intervensi & 36,39 & $-3,01$ & 0,154 \\
& Kontrol & 34,18 & & \\
Perilaku & Intervensi & 24,69 & $-2,38$ & 0,353 \\
& Kontrol & 23,63 & & \\
Afektif & Intervensi & 23,64 & $-2,01$ & 0,164 \\
& Kontrol & 21,32 & & \\
Harga Diri & Intervensi & 85,75 & $-3,13$ & 0,287 \\
& Kontrol & 79,18 & & \\
\hline
\end{tabular}

Tabel 2. Harga Diri (Kognitif, Perilaku dan Afektif) Sebelum Mengikuti Logoterapi pada Kelompok Intervensi dan Kontrol

\begin{tabular}{llccc}
\hline Komponen & Kelompok & Rerata & SD & $95 \%$ CI \\
\hline Kognitif & Intervensi & 36,39 & 3,023 & $37,22-39,56$ \\
& Kontrol & 34,18 & 5,019 & $32,23-36,12$ \\
Perilaku & Intervensi & 24,69 & 3,287 & $27,01-29,56$ \\
& Kontrol & 23,63 & 4,481 & $21,94-25,42$ \\
Afektif & Intervensi & 23,64 & 3,234 & $22,39-24,90$ \\
& Kontrol & 21,32 & 5,193 & $19,31-23,24$ \\
Harga Diri & Intervensi & 85,75 & 7,369 & $83,46-93,18$ \\
& Kontrol & 79,18 & 12,23 & $74,43-83,94$ \\
\hline
\end{tabular}


dan itu berarti bahwa nilai perubahan harga diri pada kedua kelompok tidak jauh berbeda yaitu harga diri rendah sebelum diberikan logoterapi.

Hasil analisis perubahan harga diri (kognitif, perilaku, afektif) sebelum dan sesudah diberikan logoterapi pada kelompok intervensi dan kelompok kontrol ditunjukkan pada Tabel 3.

Hasil analisis menunjukkan nilai rerata respon kognitif pada kelompok intervensi menurun 17,03 dari sebelumnya sedangkan pada kelompok kontrol penurunan itu hanya 1,50 . Hal itu menunjukkan bahwa pada kelompok intervensi terjadi perubahan kognitif kearah lebih baik yaitu 17 kali lebih besar daripada kelompok kontrol. Perubahan respon kognitif pada kelompok intervensi bermakna secara statistik sebesar $(p=0,000, \alpha=0,05)$. Dapat disimpulkan bahwa terdapat perbedaan bermakna respon kognitif pada kelompok intervensi sebelum dan sesudah pemberian logoterapi. Hasil analisis juga menunjukkan bahwa nilai rerata respon perilaku pada kelompok intervensi mengalami penurunan sebesar 17,97 dari sebelumnya sedangkan pada kelompok kontrol penurunan hanya 0,50. Hal ini menunjukkan bahwa pada kelompok intervensi terjadi perubahan perilaku yang lebih baik (17 kali), dibanding kelompok kontrol.

Perubahan respon perilaku pada kelompok intervensi juga bermakna secara statistik sebesar $0,000(\mathrm{p}<\alpha)$ dapat diartikan bahwa terdapat perbedaan yang bermakna respon dan sesudah pemberian logoterapi. Sedangkan pada respon

Tabel 3. Analisis Skor Perbedaan Harga Diri (Kognitif, Perilaku, Afektif) Responden Sebelum-Sesudah Logoterapi pada Kelompok Intervensi dan Kontrol

\begin{tabular}{lcccc}
\hline \multirow{2}{*}{ Variabel } & \multicolumn{2}{c}{ Intervensi } & \multicolumn{2}{c}{ Kontrol } \\
\cline { 2 - 5 } & Mean & $\mathrm{p}$ & Mean & $\mathrm{p}$ \\
\hline Kognitif & & & & \\
a. Sebelum & 38,39 & 0,000 & 34,18 & 0,116 \\
b. Sesudah & 21,36 & & 32,68 & \\
Perilaku & & & & \\
a. Sebelum & 28,29 & 0,000 & 23,68 & 0,500 \\
b. Sesudah & 16,32 & & 23,18 & \\
Afektif & & & & \\
a. Sebelum & 23,64 & 0,000 & 21,32 & 0,687 \\
b. Sesudah & 12,93 & & 20,96 & \\
\hline
\end{tabular}

afektif terdapat perbedaan penurunan 10 kali pada kelompok intervensi dibandingkan kelompok kontrol. Hal itu dapat diartikan bahwa pada pemberian terapi generalis dan logoterapi menyebabkan penurunan nilai rerata afektif 10 kali lebih besar daripada hanya mendapatkan terapi generalis saja. Penurunan tersebut menunjukkan bahwa pada kelompok intervensi terjadi perubahan respon afektif lebih baik dibandingkan kelompok kontrol.

Perubahan respon afektif pada kelompok intervensi juga bermakna secara statistik dengan nilai $\mathrm{p} 0,000 \quad(\mathrm{p}<\alpha)$.Peneliti menyimpulkan bahwa terdapat perbedaan yang bermakna respon afektif pada kelompok intervensi sebelum dan sesudah diberikan logoterapi. Berdasarkan hasil analisis pada tabel 3 , didapatkan bahwa nilai $p$ respon kognitif $(0,116)$, perilaku $(0,500)$ dan afektif $(0,687)$ pada kelompok kontrol lebih besar dari nilai alpha $(\alpha=0,05)$. Hal itu menunjukkan bahwa secara statistik, tidak ada perbedaan respon kognitif, perilaku dan afektif yang bermakna pada kelompok kontrol sebelum dan sesudah diberikan terapi generalis. Sedangkan pada kelompok intervensi, terdapat perbedaan yang bermakna pada respon kognitif, perilaku dan afektif sebelum dan sesudah diberikan logoterapi. Hal tersebut berarti bahwa pemberian logoterapi pada kelompok intervensi mampu mengubah harga diri (kognitif, perilaku, afektif) responden ke arah peningkatan yang lebih baik daripada sebelumnya.

Hasil analisis perubahan harga diri (kognitif, perilaku, afektif) pada kelompok intervensi dan kelompok kontrol sesudah diberikan logoterapi ditunjukkan pada Tabel 4. Tabel 4, menunjukkan

Tabel 4. Harga diri (Kognitif, Perilaku, \& Afektif) Responden Sesudah Mengikuti Logoterapi

\begin{tabular}{llcccc}
\hline Variabel & Kelompok & Rerata & SD & $\mathrm{t}$ & $\mathrm{p}$ \\
\hline Kognitif & Intervensi & 21,96 & 3,74 & & \\
& Kontrol & 32,68 & 5,47 & 9,03 & 0,000 \\
Perilaku & Intervensi & 16,32 & 3,54 & & \\
& Kontrol & 23,18 & 4,46 & 6,36 & 0,000 \\
\multirow{4}{*}{ Afektif } & Intervensi & 12,93 & 2,84 & & \\
& Kontrol & 20,96 & 5,18 & 7,19 & 0,000 \\
Harga Diri & Intervensi & 51,21 & 8,02 & & \\
& Kontrol & 76,82 & 12,5 & 7,73 & 0,000 \\
\hline
\end{tabular}


adanya perbedaan yang bermakna/signifikan perubahan harga diri (kognitif, perilaku, afektif) pada kelompok intervensi dan kontrol sesudah diberikan logoterapi dengan nilai $(\mathrm{p}=0,000$; $\alpha=0,05)$.

\section{Pembahasan}

Terdapat perubahan bermakna sebelum dan sesudah diberikan logoterapi pada kelompok intervensi dalam komponen kognitif, perilaku, afektif dan harga dirinya ( $\mathrm{p}=0,000 ; \alpha=0,05)$. Hasil ini sesuai dengan Hergenhahn,1997 yang menyebutkan teori bahwa logoterapi adalah salah satu terapi yang membangkitkan kognitif individu untuk dapat memahami potensi diri dan meningkatkan membuka situasi hidup, sehingga hidup menjadi bermakna. Melalui logoterapi, responden dilatih untuk mampu berpikir mengenali dan memahami potensi dan nilai-nilai positif diri sebagai sumber makna dalam menghadapi nilainilai negatif dan permasalahan/situasi hidup.

Hasil evaluasi sesi pertama dan kedua logoterapi menunjukkan $100 \%$ reponden dalam kelompok intervensi mampu mengungkapkan masalah, harapan dan menemukan makna hidup dalam dirinya dengan bimbingan atau panduan dari terapis. Beberapa responden mengungkapkan makna hidup yang hampir sama antara lain penyesalan, belajar, pengalaman berharga, sabar dan menolong. Frankl (Shofia, 2009) menyatakan bahwa kesabaran dan menolong termasuk dalam nilai makna sikap. Penyesalan, pengalaman termasuk nilai penghayatan. Belajar adalah nilai makna kreatif.

Keberhasilan logoterapi telah diungkapkan oleh beberapa studi sebelumnya. Caulkins, et al., (1997) yang meneliti narapidana pemakai narkotika di San Quentin \& Folsom State menemukan 8 dari 10 narapidana dalam satu kelompok mendapatkan remisi, bebas bersyarat setelah diberikan logoterapi selama dua tahun. Penelitian Mauer \& Huling (1995) di pusat rehabilitasi Norco, mengungkapkan bahwa logoterapi yang diberikan selama 1 tahun dapat meningkatkan kebermaknaan hidup pasien pemakai narkotika dan menurunkan angka ketergantungan narkotika dari $45 \%$ menjadi $11 \%$.
Hasil penelitian tersebut selaras dengan hasil penelitian ini. Peneliti pada sesi ketiga logoterapi responden pada kelompok intervensi mampu melakukan atau mendemonstrasikan berbagai kegiatan harian yang dapat memunculkan makna/ hikmah didalamnya. Contohnya adalah kegiatan menyiram dan memelihara tanaman dengan memaknainya sebagai kegiatan yang memberikan kehidupan buat makhluk Tuhan.

Responden memaknai kegiatan menyulam dan membuat kerajinan tangan sebagai kegiatan yang dapat menghapuskan dosa akibat perbuatan sebelumnya yaitu menjual narkotika. Setiap kegiatan selama berada di Lapas dimaknai berbeda-beda, tergantung dari penilaian diri setiap orang. Hal ini sesuai Gutsman (1996) dan Fromm (1997) yang menyatakan bahwa ada tiga cara menemukan makna hidup yaitu melalui aktivitas yang kreatif atau karya cipta yang inovatif, nilai-nilai interaksi dengan orang lain, dan melalui penderitaan. Pemaknaan ini bermanfaat untuk meningkatkan motivasi hidup, mempertahankan perilaku adaptif, mengurangi rasa bosan/dan jenuh, dan menimbulkan rasa bahagia.

Pada respon afektif, responden dalam kelompok intervensi mampu mengungkapkan perasaannya terkait dengan pengalaman yang dijalaninya selama berada di Lapas, seperti perasaan sedih, menyesal, cemas, sayang, senang, dan rindu. Kegiatan logoterapi memberikan kebebasan untuk mengungkapkan masalah, yang bertujuan untuk memperoleh gambaran nilai individu terutama nilai penghayatan yang hilang dari dalam dirinya.

Menurut Frankl (Shofia, 2009) nilai penghayatan merupakan salah satu sumber untuk menemukan makna. Mendalami nilainilai penghayatan berarti mencoba memahami meyakini, dan menghayati berbagai nilai yang ada dalam kehidupan seperti keindahan, kebajikan, kebenaran, keimanan dan cinta kasih (Bastaman, 2007). Menghayati cinta kasih, misalnya dapat menimbulkan perasaan bahagia, kepuasan, ketentraman perasaan diri berharga dan bermakna. Penghayatan erat kaitannya dengan perasaan (Wong, 2000). Berdasarkan penjelasan diatas, 
penulis menetapkan asumsi bahwa keberhasilan peningkatan harga diri (kognitif, perilaku, afektif) pada kelompok intervensi disebabkan pelaksanaan logoterapi sesuai dalam empat sesi. Selain itu, sikap, motivasi dan dukungan anggota kelompok juga berperan dalam keberhasilan logoterapi tersebut.

Hasil penelitian ini menemukan perbedaan antara hasil pada kelompok intervensi dan kelompok kontrol. Hal tersebut sesuai dengan teori yang menyebutkan bahwa terapi aktivitas kelompok bersifat generalis atau umum yang memunculkan pada keaktifan atau keikusertaan responden mengikuti kegiatan di suatu tempat (Keliat, 2002). Salah satunya adalah terapi aktivitas kelompok stimulasi persepsi. Tujuan dari TAK stimulasi persepsi adalah membantu responden untuk meningkatkan kemampuan dalam menyelesaikan masalah yang diakibatkan oleh paparan stimulus kepadanya (Darsana, 2007). Adapun stimulus yang dimaksud dapat berupa pemikiran dan penilaian negatif tentang dirinya.

Pada kegiatan Terapi Aktivitas Kelompok (TAK), responden hanya dilatih untuk mampu berpikir menemukan kelebihan dan kekurangan dirinya. Responden tidak dilatih untuk mengubah pemikiran/kognitif negatif atau menemukan makna dibalik penilaian atas kekurangan dirinya sehingga tidak ada penyelesaian masalah secara langsung bagi responden. Selain itu, responden lebih memperhatikan pada penilaian kemampuan diri masing-masing sehingga komunikasi/ interaksi diantara anggota kelompok untuk memberikan reinforcement/ pujian positif juga berkurang.

Pada kegiatan TAK, responden dilatih untuk melakukan kemampuan positifnya dalam aktivitas/ kegiatan atau perilaku sehari-hari. Selain itu responden mendapat kesempatan untuk mengungkapkan perasaan/afektif terkait dengan yang dialaminya. Namun, menurut asumsi peneliti, kondisi tersebut tidak memberikan perubahan harga diri (kognitif, perilaku, afektif) responden pada kelompok kontrol dikarenakan kemampuan positif yang diaktualisasikan dalam perilaku tidak bertahan lama, serta perasaan/afektif yang diungkapkan responden tidak mendapatkan respon untuk diselesaikan.

Hasil penelitian menemukan perbedaan antara kelompok intervensi dan kontrol setelah kelompok intervensi mendapatkan logoterapi. Sebanyak 90\% responden pada kelompok intervensi mengemukakan masalah ketergantungan narkotika. Kehidupan mereka telah dikendalikan oleh narkotika yang dilatarbelakangi kemiskinan, konflik keluarga dan kepercayaan diri yang rendah sehingga membuat mereka merasa hampa, kosong, bosan, tidak berdaya, dan tidak bermakna. Keadaan yang dialami responden ini disebut existensial vakum. Penelitian Noblejas de la Flor (1997) di pusat rehabilitasi Naval di Afrika Selatan menemukan 80 dari 115 pemakai narkotika mengalami kehampaan hidup, kebosanan dan ketidakjelasan tujuan hidup. Respon psikologis/ emosional yang dialami pemakai narkotika tersebut merupakan hasil proses kognitif berupa penilaian dan penerimaan makna dalam situasi tertentu yang sedang kita alami pada saat ini. Kegiatan logoterapi bertujuan membantu seseorang menemukan makna hidup sehingga tujuan hidup dan kebahagiaan dapat dicapai (Kausch \& Amer, 2007). Ada tiga cara dalam logoterapi yang dapat ditempuh manusia untuk menemukan makna hidup; pertama melalui pekerjaan atau perbuatan; kedua dengan mengalami sesuatu atau melalui seseorang; dan yang ketiga melalui cara individu menyikapi penderitaan yang tidak bisa dihindari (Frankl, 2000). Proses ini merupakan proses kognitif untuk menemukan dan menerima makna. Pada penelitian ini, responden pada kelompok intervensi menunjukkan perubahan kognitif yang lebih baik dibandingkan kelompok kontrol.

Respon kognitif responden pada kelompok kontrol tidak banyak mengalami perubahan. Terapi yang diberikan pada kelompok kontrol adalah TAK stimulasi persepsi yang menggunakan aktivitas sebagai stimulus terkait dengan penilaian dan pengalaman diri masing-masing anggota kelompok dengan masalah keperawatan yang sama (Gillien, 2001). Responden dilatih mengenal/mengidentifikasi kemampuan positif diri. Namun, dalam pelaksanaannya, responden mengalami kesulitan 
melakukannya. Hal ini dapat terjadi karena mereka menganggap bahwa kemampuannya merupakan sesuatu yang wajar atau biasa saja, sama dengan kemampuan orang lain.

Hasil perubahan perilaku pada kelompok intervensi lebih baik dibandingkan dengan kelompok kontrol. Pada kegiatan logoterapi, responden mendapatkan penguatan positif dari dalam dan dari luar yaitu dukungan dan penerimaan dari anggota kelompok lainnya. Penguatan positif dari dalam diperoleh dari penghayatan dan keyakinan individu terhadap nilai kreatif yang dimilikinya sebagai salah satu sumber makna atau potensi yang menimbulkan makna bagi kehidupannya (Shantall, 1999). Nilai kreatif dapat dicapai melalui berbagai perilaku atau kegiatan yang terarah. Kegiatan atau perilaku terarah, yaitu upaya yang dilakukan secara sadar dan sengaja berupa pengembangan potensi diri (bakat, kemampuan, keterampilan) yang positif serta pemanfaatan relasi antar pribadi untuk menunjang tercapainya makna dan tujuan hidup (Weber, 2002).

Responden pada kelompok kontrol, hanya melakukan kegiatan yang berkaitan dengan kemampuan positif yang dimilikinya tanpa ada kebutuhan dan alasan/sumber makna sehingga kegiatan yang dilaksanakan bersifat rutin dan dilakukan dengan terpaksa hanya akan menguatkan identitas atas kemampuan positif yang dimilikinya. Katz (1960, dalam Depkes 2002) menjelaskan perubahan perilaku individu tergantung kebutuhan.

Hasil perubahan afektif pada kelompok intervensi lebih baik daripada kelompok kontrol. Melalui logoterapi, responden dilatih untuk membuka diri dalam rangka menemukan potensi makna yang baru di balik penderitaan, rasa kehilangan dan bersalah yang dialami selama di Lapas. Perubahan sikap memberikan umpan balik positif yang membantu manusia menjadi lebih terbuka dan memudahkan dalam mencari makna dan arti baru dalam situasi krisis atau penderitaan.

Responden pada kelompok kontrol hanya menunjukkan perubahan sikap dalam mengambil keputusan untuk mengikuti kegiatan kelompok secara mandiri dan sebagian responden perlu dukungan moral. TAK tidak dapat memfasilitasi untuk menyelesaikan masalah dan perasaan yang dialami mereka sebelumnya. TAK yang diberikan pada kelompok kontrol belum mampu memenuhi kebutuhan perasaan yang dialami responden.

\section{Kesimpulan}

Terdapat perbedaan yang signifikan harga diri (respon kognitif, perilaku dan afektif) sebelum dan sesudah logoterapi pada kelompok intervensi Hasil berbeda ditemukan pada kelompok kontrol yaitu tidak ada perbedaan harga diri (respon kognitif, perilaku dan afektif) sebelum dan sesudah pelaksanaan terapi aktivitas kelompok. Dapat disimpulkan bahwa logoterapi merupakan terapi yang bermanfaat untuk membantu seseorang untuk meningkatkan konsep diri khususnya harga diri yang diperoleh dari penerimaan diri secara kognitif, afektif dan perubahan perilaku yang adaptif. Hasil penelitian ini memperkaya rujukan tentang manfaat logoterapi pada populasi narapidana. Terapi ini dapat dipertimbangkan untuk diterapkan pada narapidana di Lapas dengan pelaksana seorang perawat yang mempunyai kewenangan dan kompetensi melakukan logoterapi (MR,AG)

\section{Referensi}

Asagba, R.B. (2009). Logotherapeutic Management of persons with substance abuse/dependence. Ife Psychologia, 17 (1). Diperoleh dari: https://www.questia.com/library/journal/1P31868494141/logotherapeutic-managementof-persons-with-substance.

Bastaman, H.D. (1996). Meraih hidup bermakna kisah pribadi dengan pengalaman tragis. Jakarta: Paramadina.

(2007). Logoterapi: Psikologi untuk menemukan makna hidup dan meraih hidup bermakna. Jakarta: Raja Grafindo.

Caulkins, J.P. (1997). Are mandatory minimum drug sentences cost-effective? Santa Monica, 
CA: RAND Corporation. Diperoleh dari: http://www.rand.org/pubs/research_briefs/ RB6003.html.

Darsana. (2007). Gangguan mental dan perilaku akibat narkoba. Disampaikan pada Seminar tentang Narkoba di Universitas Airlangga, Surabaya.

Depkes RI. (2002). Pedoman nasional penanggulangan tuberkulosis. Jakarta: Depkes RI.

Ferszt, G.G., Hickey, J.E., \& Seleyman, K. (2013). Advocating for pregnant women in prison: The role of the correctional nurse. Journal of Forensic Nursing, 9 (2), 105-110. doi: 10.1097/JFN.0b013e318281056b

Frankl, V.E. (2000). On the theory and therapy of mental disorders: An introduction to logotherapy and existential analysis. New York and Hove: Brunner-Routlede Taylor \& Francis Group.

Gillien, R. (2001). Purpose in life and self perceived anger problem among college students. International Forum for Logotherapy, 18, 74-82.

Gutsman, D. (1996). Logotherapy for helping profesional: Meaningful social work. New York: Springer.

Hazell, R.R., \& Windmill, M.E. (2000). The use of logotheraphy tehnique in thetreatment of multiple personally disorder. Diperoleh dari http://www.webspace.ship.edu/cgboes/ .Frankl.html.

Hergenhahn, B.R., \& Henley, T.B. (2013). An introduction to the history of psychology (7th Ed.). Belmont, CA: Wadsworth Publishing.

Inayatika. (2011). Self efficacy pada narapidana di lapas kelas I Palembang (Skripsi, Tidak dipublikasi). Program Studi Ilmu Keperawatan UNSRI, Palembang.

James, D.J., \& Glaze, L.E. (2006). Beraue of justice statistic special report: Mental health problem of prison and jail inmates. Diperoleh dari: https://www.bjs.gov/content/ pub/pdf/mhppji.pdf.
Kausch, K.D., \& Amer, K. (2007). Selftranscendence and depression among AIDS memorial quilt panel makers. $J$ Psychosoc Nurs Ment Health Serv., 45(6), 44-53.

Keliat, B.A., \& Akemat. (2005). Keperawatan jiwa terapi aktivitas kelompok. Jakarta : EGC.

Koesno, A. (2007). Faktor-faktor kriminogenik perempuan melakukan kejahatan narkotika. Jurnal Yustika, 10 (2), 153-170.

Mauer, M. \& Huling, T. (1995). Young black Americans andthe criminal justice system: Five years later. Diperoleh dari: http://www. sentencingproject.org/wp-content/uploads/ 2016/01/Young-Black-Americans-and-theCriminal-Justice-System-Five-Years-Later. Pdf.

Mujiran, P. (2006). Kejahatan dan gangguan jiwa. Diperoleh dari http://groups.yahoo.com/.

Noblejas de la Flor, M.A. (1997). Meaning levels and drug-abuse therapy: An empirical study. International Forum for Logotherapy; 20, $46-51$.

Nova.S. (2008). Tingkat depresi pada narapidana wanita di lembaga pemasyarakatan IIA Palembang (Skripsi, Tidak Dipublikasi). Program Studi Ilmu Keperawatan UNSRI, Palembang.

Pujianto, R. (2010). Angka pengangguran. Diperoleh dari: http://www.MediaIndonesia.com.

Ramdani, B. (2005).Upaya mengatasi stress narapidana saat menjalani pidana penjara di lembaga pemasyarakatan melalui rancangan program okulasi stress. Tesis Tidak Dipublikasi. Depok: Fakultas Hukum Universitas Indonesia.

Shantall, T. (1999). What is meant by meaning? In F.Crous, A.A. Havenga Coetzer \& G. Van den Heever (Eds). On the way to meaning: Essays in remambrance of Viktor Frankl; (pp.57-72). Benmore: Viktor Frankl Foundation of South Africa.

Shofia, F. (2009). Optimisme masa depan narapidana (Skripsi, Tidak Dipublikasi). Fakultas 
Psikologi Universitas Muhammadiyah Surakarta, Surakarta.

Sutejo, Keliat, B.A., Sutanto Priyo Hastono, S.P., \& Daulima, NHC. (2011). Penurunan ansietas melalui logoterapi kelompok pada penduduk pasca-gempa di Kabupaten Klaten. Jurnal Keperawatan Indonesia, 14 (2), 107-112.

Undang-Undang Republik Indonesia No. 23 tahun 1992 tentang Kesehatan.

Videbeck, S.L. (2008). Psychiatric mental health nursing. (4rd Ed.). Philadelphia: Lippincott Williams \& Wilkins.
Weber, K., \& Stefen, A. (2002). The hidden crisis: Women in prison. San Fransisco: National Council and Crime Delincquency.

Wong, P.T.P. (2000). Implicit theories of personal life and the development of the personal meaning profile. The human quest for meaning: A handbook of psychologycal research and clinical applications. Mahwah, N.J: Lawrence Erlbraum Associates. 